\title{
L-myo-Inositol-1-phosphate synthase from bryophytes: purification and characterization of the enzyme from Lunularia cruciata (L.) Dum.
}

\section{Dhani Raj Chhetri'*, Sachina Yonzone', Sanjeeta Tamang' and Asok Kumar Mukherjee ${ }^{2}$}

\footnotetext{
${ }^{1}$ Plant Physiology and Biochemistry Laboratory, Post Graduate Department of Botany, Darjeeling Government College, Darjeeling-734 101, WB, India.

${ }^{2}$ Department of Biotechnology, Bengal College of Engineering and Technology Bidhan Nagar, Durgapur-713 212, WB, India.
} *Corresponding author. Post box No. 79, Darjeeling-H.P.O., Darjeeling-734 101, WB, India; e-mail: dhanirajc@gmail.com
Received: 07 January 2009; Accepted: 28 October 2009.

\begin{abstract}
L-myo-inositol-1-phosphate synthase (MIPS; EC: 5.5.1.4) catalyzes the conversion of D-glucose-6-phosphate to 1L-myo-inositol1-phosphate, the rate limiting step in the biosynthesis of all inositol containing compounds. Myo-inositol and its derivatives are implicated in membrane biogenesis, cell signaling, salinity stress tolerance and a number of other metabolic reactions in different organisms. This enzyme has been reported from a number of bacteria, fungi, plants and animals. In the present study some bryophytes available in the Eastern Himalaya have been screened for free myo-inositol content. It is seen that Bryum coronatum, a bryopsid shows the highest content of free myo-inositol among the species screened. Subsequently, the enzyme MIPS has been partially purified to the tune of about 70 fold with approximately $18 \%$ recovery form the reproductive part bearing gametophytes of Lunularia cruciata. The $L$. cruciata synthase specifically utilized D-glucose-6-phosphate and NAD+ as its substrate and co-factor respectively. The optimum pH shown was 7.0 while the temperature maximum was at $30^{\circ} \mathrm{C}$. The enzyme activity was slightly stimulated by $\mathrm{Mg}^{2+}$ and $\mathrm{Ca}^{2+}$; remarkably stimulated by $\mathrm{NH}_{4}^{+}$; slightly inhibited by $\mathrm{Mn}^{2+}$; highly inhibited by $\mathrm{Cu}^{2+}, \mathrm{Zn}^{2+}$ and $\mathrm{Hg}^{2+}$. The $K_{\mathrm{m}}$ values for D-glucose-6-phosphate and $\mathrm{NAD}^{+}$was found to be 0.80 and $0.034 \mathrm{mM}$ respectively while the $V_{\max }$ values were 2.8 and $1.21 \mathrm{mM}$ for D-glucose-6-phosphate and NAD+ respectively.
\end{abstract}

Key words: D-glucose-6-phosphate, inositol monophosphatase, inositol synthase, myo-inositol, L-myo-inositol-1-phosphate,

Abbreviations: G-6-P = D-glucose-6-phosphate, I-1-P = Inositol-1-phosphate

ME $=$ 2-mercaptoethanol, MIPS $=$ L-myo-inositol-1-phosphate synthase

\section{INTRODUCTION}

Inositols are 6-Carbon cyclohexane cyclitols found ubiquitously in biological kingdom. The essential role of inositol in many cellular processes including membrane formation, cell wall biogenesis, stress response and signal transduction have been well documented (Lackey et al., 2003). Myo-inositol is the precursor of all inositol containing compounds including phosphoinositides, inositol phosphates and cell wall polysaccharides (Biswas et al., 1984; Loewus and Murthy, 2000). The de-novo synthesis of myo-inositol takes place by the conversion of D-glucose-6-phosphate (G-6-P) to L-myo-inositol-1-phosphate (I-1-P) by the enzyme L-myo-inositol-1-phosphate synthase (MIPS; EC 5.5.1.4) which is subsequently dephosphorylated by a specific 
$\mathrm{Mg}^{+2}$ dependent inositol monophosphatase to myo-inositol. The MIPS reaction has been reported from archea (Chen et al. 2000); bacteria (Bachhawat and Mande, 1999, 2000); protozoa (Lohia et al. 1999); animals (Maeda and Eisenberg, 1980; Mauck et al., 1980; Biswas et al., 1981); humans (Adhikari and Majumder, 1988) and plants. Among plants the occurrence of MIPS has been described and characterized from algae (Dasgupta et al., 1984; RayChaudhuri et al., 1997); fungi (Donahue and Henry, 1981a,b; Escamilla et al. 1982; Dasgupta et al. 1984); pteridophytes (Chhetri et al. 2005, 2006a); gymnosperm (Gumber et al., 1984; Chhetri and Chiu, 2004) and angiosperm (Loewus and Loewus, 1971; Johnson and Sussex, 1995; Johnson and Wang, 1996; RayChaudhuri et al., 1997). The present study is the first report detailing the partial purification and characterization of MIPS from a bryophyte, Lunularia cruciata occurring in the Darjeeling hills of Eastern Himalayas.

\section{MATERIALS AND METHODS}

Plant material: Fresh specimens of bryophytes like Marchantia nepalensis Lehm. \& Lindenb., Lunularia cruciata (L.) Dum., Asterella tenella (L.) Beauv., Notothylas indica Kash. and Bryum coronatum Schwaegr were collected from the localities in and around Darjeeling hills (circa $2134 \mathrm{~m}$

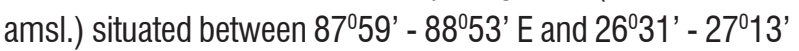
$\mathrm{N}$ in the Eastern Himalaya of India.

Free myo-inositol determination: Free myo-inositol was isolated by the method of Charalampous and Chen (1966). The extracted sample was passed through a mixed bed column of Dowex-1-Cl (100-200 mesh) and Amberlite IR-120 (Naform) and the free myo-inositol was ultimately isolated by one dimensional descending chromatography through Whatman No.1 paper. The content of free myo-inositol was estimated spectrophotometrically (Gaitonde and Griffiths, 1966) using a standard curve prepared using known concentrations of pure myo-inositol.

Extraction and partial purification of MIPS from Lunularia cruciate: Reproductive part bearing Lunularia cruciata thallus $(50 \mathrm{~g})$ was collected fresh in the morning, washed twice with cold, sterile distilled water and homogenized in a chilled mortar and pestle in half the volume of $50 \mathrm{mM}$ tris-acetate ( $\mathrm{pH} 7.5)$ buffer containing 0.2 $\mathrm{mM}$ ME. The crude homogenate was passed through four layers of muslin and the liquid was centrifuged at $1,000 \times g$ for $5 \mathrm{~min}$. The supernatant was centrifuged at $11,400 \times \mathrm{g}$ for 20 min and the resulting supernatant was collected again, dialyzed overnight against $50 \mathrm{mM}$ tris-acetate ( $\mathrm{pH} 7.5$ ) buffer containing $0.2 \mathrm{mM} \mathrm{ME}$ and the clear supernatant recovered from the dialysis bag $(11,400 \times g$ supernatant) was used as the enzyme source for the initial screening experiments. The $11,400 \times g$ supernatant from $L$. cruciata was subjected to streptomycin sulphate treatment to a final concentration of $2 \%(\mathrm{w} / \mathrm{v})$ with constant stirring. The mixture was kept in ice-bucket at $0^{\circ} \mathrm{C}$ for $15 \mathrm{~min}$ and then centrifuged at $11,400 \times g$ for $15 \mathrm{~min}$. The supernatant (streptomycin sulphate treated fraction) was collected which and was made $0-60 \%$ saturated by slowly adding ammonium sulphate. The precipitated protein fraction was dissolved in minimal volume of tris-acetate buffer $(\mathrm{pH} 7.5)$ containing $0.2 \mathrm{mM}$ ME and dialyzed against the same buffer with one change. The dialyzed fraction (ammonium sulphate treated fraction) was adsorbed for $3 \mathrm{~h}$ on DEAE-cellulose (pre-equilibrated with the extraction buffer) and the preparation was loaded in a $8 \times 1.2 \mathrm{~cm}$ glass column. The column was washed with the extraction buffer and the adsorbed proteins were eluted from the column with a linear gradient of 0 to $0.5 \mathrm{M} \mathrm{KCl}$ in $60 \mathrm{~cm}^{3}$ extraction buffer. Fractions $\left(2.0 \mathrm{~cm}^{3}\right)$ were collected at an interval of 8 minutes. The enzyme was eluted between $\mathrm{KCl}$ concentrations of 0.22 to $0.27 \mathrm{M}$ (Fig. 1). The active DEAE-cellulose purified synthase (DEAE-cellulose fraction) was further purified by molecular sieve chromatography on a Sephadex G-200 column $(7.5 \times 0.8 \mathrm{~cm})$ pre-equilibrated with the extraction buffer and the enzyme was eluted from the column with the same buffer. Fractions of $0.75 \mathrm{~cm}^{3}$ were collected at a flow rate of $10 \mathrm{~min}_{\text {fraction }}{ }^{-1}$. The active Sephadex G-200 purified fractions were pooled together (Sephadex G-200 fraction), concentrated and used as the ultimate preparation in this experiment.

Assay of MIPS: The MIPS activity was assayed by the procedure of Barnett et al., (1970) with slight modifications (Adhikari et al., 1987). The assay mixture contained $50 \mathrm{mM}$ tris-acetate ( $\mathrm{pH} 7.5), 14 \mathrm{mM} \mathrm{NH}_{4} \mathrm{Cl}, 0.8 \mathrm{mM} \mathrm{NAD}{ }^{+}, 5 \mathrm{mM}$ ME, $5 \mathrm{mM}$ G-6-P and an appropriate aliquot (100-200 $\mu \mathrm{g}$ ) of enzyme protein in a total volume of $0.5 \mathrm{~cm}^{3}$. After incubation at $37^{\circ} \mathrm{C}$ for $1 \mathrm{~h}$, the reaction was terminated by $0.2 \mathrm{~cm}^{3}$ of $20 \%$ chilled TCA. An equal volume of $0.2 \mathrm{M} \mathrm{NaIO}_{4}$ was added to the deproteinized supernatant $\left(0.7 \mathrm{~cm}^{3}\right)$ followed by a second incubation at $37^{\circ} \mathrm{C}$ for $1 \mathrm{~h}$ for the oxidation 
of MIPS reaction product, myo-insositol-1-phosphate, with concomitant release of inorganic phosphate. The excess of periodate was destroyed by $1 \mathrm{M} \mathrm{Na}_{2} \mathrm{SO}_{3}$. Simultaneously, appropriate non-periodate controls, in which $\mathrm{NaIO}_{4}$ and $\mathrm{Na}_{2} \mathrm{SO}_{3}$ treatments were omitted were also run. The activity of the enzyme was determined by estimating the product-specific release of inorganic phosphate from myo-inositol-1-phosphate by MIPS reaction. Inorganic phosphate was determined by the method of Chen et al. (1956). The inorganic phosphate released was quantified with a standard curve prepared using $\mathrm{K}_{2} \mathrm{HPO}_{4}$. Protein was determined according to the method of Bradford (1976) with BSA as a standard. The protein content in fractions obtained from column chromatography was determined by measuring absorbance at $280 \mathrm{~nm}$.

\section{RESULTS}

Determination of free myo-inositol from bryophytes: Appreciable quantity of free myo-inositol (the final product of myo-inositol biosynthesis) was detected from vegetative and reproductive parts of different bryophytic species (Table 1). It was revealed that the quantities of free myo-inositol in almost all plant parts were moderately high. Free myo-inositol content was detected in relatively large quantities in the reproductive part bearing thallus of Marchantia nepalensis, Bryum coronatum and Notothylas indica while the same in the vegetative thallus of Bryum coronatum was also noteworthy (Table 1). Different inositol derivatives are known to be essential for all life forms (Majumder et al., 2003) especially in the formation of sex units. Hence, the detection of free myo-inositol in these bryophytes with higher content of the same in the reproductive parts is justified.

Table 1. Distribution of free myo-inositol in vegetative and reproductive structures of different bryophytic species (values are mean $\pm \mathrm{SE}$ ), FW $=$ fresh weight.

\begin{tabular}{|c|c|c|c|c|}
\hline Class & Family & Plant species & Plant part & $\begin{array}{l}\text { Free myo-inositol content } \\
\text { (mg/g FW) }\end{array}$ \\
\hline Hepaticopsida & Marchantiaceae & Marchantia nepalensis & $\begin{array}{l}\text { Vegetative } \\
\text { Reproductive }\end{array}$ & $\begin{array}{l}1.23 \pm 0.10 \\
2.88 \pm 0.23\end{array}$ \\
\hline Hepaticopsida & Marchantiaceae & Lunularia cruciata & $\begin{array}{l}\text { Vegetative } \\
\text { Reproductive }\end{array}$ & $\begin{array}{l}0.50 \pm 0.10 \\
0.80 \pm 0.09\end{array}$ \\
\hline Hepaticopsida & Aytoniaceae & Asterella tenella & $\begin{array}{l}\text { Vegetative } \\
\text { Reproductive }\end{array}$ & $\begin{array}{l}1.52 \pm 0.14 \\
1.00 \pm 0.17\end{array}$ \\
\hline Anthocerotopsida & Notothylaceae & Notothylas indica & $\begin{array}{l}\text { Vegetative } \\
\text { Reproductive }\end{array}$ & $\begin{array}{l}0.55 \pm 0.04 \\
2.00 \pm 0.20\end{array}$ \\
\hline Bryopsida & Bryaceae & Bryum coronatum & $\begin{array}{l}\text { Vegetative } \\
\text { Reproductive }\end{array}$ & $\begin{array}{l}2.10 \pm 0.11 \\
2.25 \pm 0.22\end{array}$ \\
\hline
\end{tabular}

Purification of the enzyme: The enzyme MIPS was isolated and purified from the reproductive thallus of freshly collected $L$. cruciata employing the techniques of low speed centrifugation, streptomycin sulphate precipitation, ammonium sulphate fractionation, ion-exchange chromatography through DEAE-cellulose and molecular sieve chromatography through Sephadex G-200. The summary of the purification of MIPS is given in Table 2. Chromatographic profiles of proteins resolved from ammonium sulphate fraction of the reproductive thallus of $L$. cruciata are shown in Figures 1 and 2. An overall purification of the enzyme to about 70 fold with about 18 $\%$ recovery based on total activity could be achieved in the present study. 


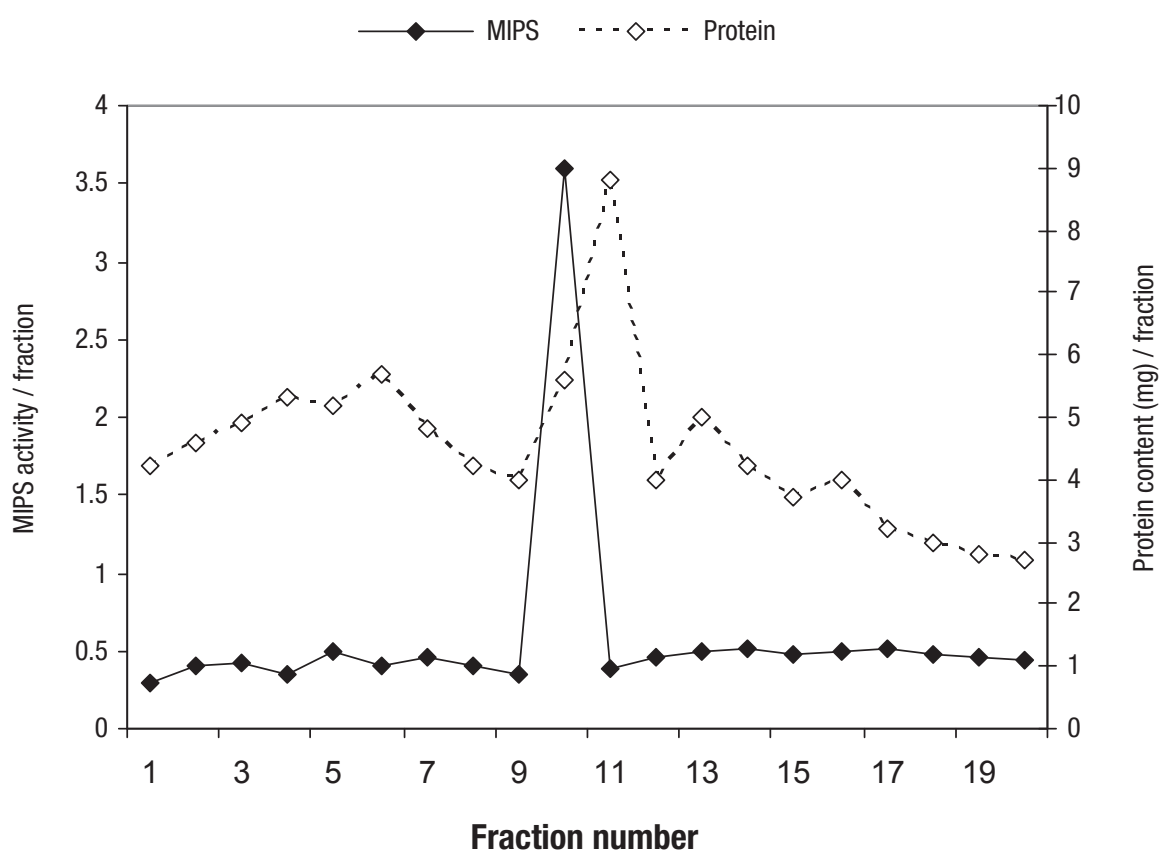

Figure 1. Elution profile of Lunularia cruciata MIPS on DEAE-cellulose column. MIPS activity is expressed as $\left[\mu \mathrm{mol}(\mathrm{I}-1-\mathrm{P})\right.$ produced fraction $\left.^{-1} \mathrm{~h}^{-1}\right]$.

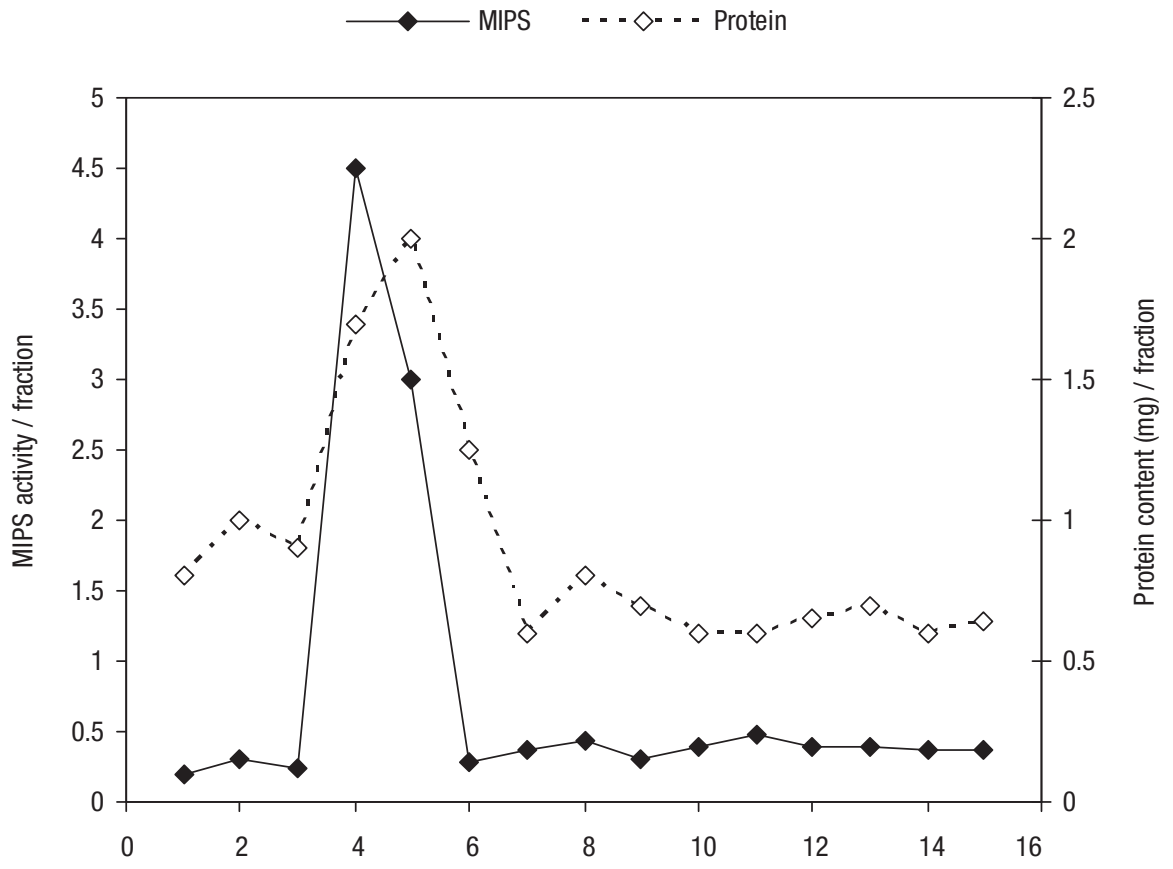

Fraction number

Figure 2. Elution profile of Lunularia cruciata MIPS on Sephadex G-200 column. MIPS activity is expressed as [ $\mu$ mol (I-1-P) produced fraction $\left.{ }^{-1} h^{-1}\right]$. 
Characterization of the purified enzyme: The L. cruciata MIPS when assayed in presence of $50 \mathrm{mM}$ tris acetate buffer (pH 7.5), $14 \mathrm{mM} \mathrm{NH}_{4} \mathrm{Cl}, 0.8 \mathrm{mM} \mathrm{NAD}{ }^{+}, 5 \mathrm{mM} \mathrm{ME}$ and $5 \mathrm{mM}$ G-6-P recorded maximal activity (Table 3). When the specific substrate (G-6-P) was not added in the incubation mixture, the enzymatic synthesis of L-myo-inositol-1-phosphate could not be detected. Deduction of NAD+ (co-enzyme) resulted in the loss of enzyme activity by about $60 \%$. In comparison, the deduction of $\mathrm{NAD}^{+}$resulted in the loss of enzyme activity by $70 \%$ in Euglena gracilis (Dasgupta et al. 1984). About $25 \%$ activity was lost when tris-buffer was omitted from the reaction mixture. Absence of either ammonium ion or ME decreased the enzyme activity to about $62 \%$ and $73 \%$ respectively, as compared to the complete set.

Kinetic studies were carried out using G-6-P (substrate) in the range of 0-8 $\mathrm{mM}$. The reaction rate was found to increase linearly with respect to G-6-P up to a concentration of $4 \mathrm{mM}$. The $K_{\mathrm{m}}$ value for $\mathrm{G}-6-\mathrm{P}$, as determined by Lineweaver-Burk plot was $0.80 \mathrm{mM}$ which is comparable to the same for the pteridophytic enzyme having a value of 0.83 (Chhetri et al., 2006a). The $V_{\max }$ value of this bryophytic enzyme was calculated as $2.80 \mathrm{mM}$ as against $1.6 \mathrm{mM}$ for the Yeast enzyme (Donahue and Henry, 1981b) and 1.42 $\mathrm{mM}$ for the pteridophytic enzyme (Chhetri et al. 2006a). Though this value differs widely from other plant species, it corresponds to the $V_{\max }$ value of 2.95 reported for Taxus baccata (Chhetri and Chiu, 2004). Between concentrations of 0-1.0 mM of NAD (co-enzyme) the increase in co-enzyme concentration up to $0.5 \mathrm{mM}$ resulted in the enhancement of enzyme activity. The $K_{\mathrm{m}}$ of $\mathrm{NAD}^{+}$was determined as 0.03 which was quite different from those recorded for the enzyme from other sources e.g. $8.00 \mathrm{mM}$ for the Yeast enzyme (Donahue and Henry, 1981b) and and 0.44 for the pteridophytic enzyme (Chhetri et al. 2006a). The $V_{\max }$ value of NAD ${ }^{+}$for the $L$. cruciata MIPS was found to be $1.21 \mathrm{mM}$ which is comparable to that of yeast having a value of 1.14 mM (Donahue and Henry, 1981b) but different from those of pteridophytic enzyme which exhibits a $V_{\max }$ value of $1.80 \mathrm{mM}$ (Chhetri et al., 2006a).

Stability of the MIPS enzyme varied at different stages of purification. While the $11,400 \times g$ supernatant remained active for 8-10 days when stored at $-20^{\circ} \mathrm{C}$, the Sephadex G-200 purified fractions maintained its activity only up to 3-4 days when stored at identical temperature. However, repeated freezing and thawing resulted in remarkable loss of activity. Addition of enzyme stabilizer, 2-mercaptoethanol (ME) or dithiothreitol (DTT) considerably increased the activity of the enzyme.

Enzyme activity linearity of $L$. cruciata MIPS was seen up to $300 \mu \mathrm{g}$ of protein concentration under standard assay conditions (Fig. 3). The temperature maximum was found to be at $30^{\circ} \mathrm{C}$ which is slightly low as the enzymes from other sources are optimally active between $35^{\circ}$ and $37{ }^{\circ} \mathrm{C}$ (RayChoudhuri et al., 1997). The L. cruciata enzyme exhibited a pH optima of 7.0 which is too lower as compared to that of other plant species like Spirulina platensis-7.8, Euglena gracilis-8.2 (RayChoudhuri et al. 1997) and Acer pseudoplatanus-8.0 (Loewus and Loewus, 1971).

Effect of different metal ions on L. cruciata MIPS activity was tested in $5 \mathrm{mM}$ concentrations using chloride salts of metal ions. Among monovalent cations tested, $\mathrm{K}^{+}$had little effect and $\mathrm{Na}^{+}$played an inhibitory role while $\mathrm{NH}_{4}{ }^{+}$was an appreciable stimulator of the enzyme. $\mathrm{NH}_{4}{ }^{+}$stimulation of the enzyme was to the tune of 1.4 times in contrast to the Acer pseudoplatanus (Loewus and Loewus, 1971) MIPS which is stimulated by 2.3 times with $\mathrm{NH}_{4}{ }^{+}$. Among the divalent cations it was found that $\mathrm{Ca}^{2+}$ and $\mathrm{Mg}^{2+}$ slightly stimulated; $\mathrm{Mn}^{2+}$ slightly inhibited, $\mathrm{Cu}^{2+}, \mathrm{Zn}^{2+}$ and $\mathrm{Hg}^{2+}$ strongly inhibited the enzyme activity with $\mathrm{Hg}^{2+}$ acting as the strongest (80\%) inhibitor (Table 4).

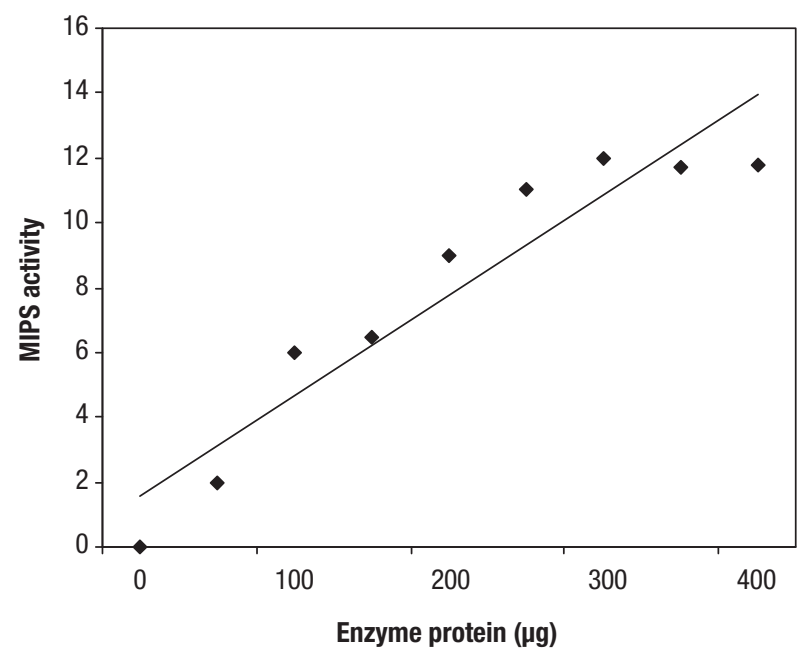

Figure 3. Effect of different enzyme concentration on Lunularia cruciata MIPS. MIPS activity is expressed as $\left[\mu \mathrm{mol}(\mathrm{I}-1-\mathrm{P})\right.$ produced $\mathrm{mg}^{-1}$ (protein) $\left.\mathrm{h}^{-1}\right]$. 
Table 2. Summary of partial purification of L-myo-inositol-1-phosphate synthase from reproductive part bearing thallus of Lunularia cruciata (values are mean \pm SE).

\begin{tabular}{lccccc}
\hline Fraction & Total protein $[\mathrm{mg}]$ & $\begin{array}{c}\text { Specific activity } \\
{[\mu \text { mol (L-myo-inositol-1- }} \\
\text { phosphate) } \mathbf{m g}^{-1}\left(\text { protein) } \mathbf{h}^{-1}\right]\end{array}$ & $\begin{array}{c}\text { Total activity } \\
{[\mu \text { mol (L-myo-inositol-1- }} \\
\left.\text { phosphate) } \mathbf{h}^{-1}\right]\end{array}$ & $\begin{array}{c}\text { Recovery } \\
{[\%]}\end{array}$ & $\begin{array}{c}\text { Purification } \\
{[\text { [fold] }}\end{array}$ \\
\hline Homogenate & $204.4 \pm 9.71$ & $0.12 \pm 0.01$ & $24.52 \pm 3.51$ & $100.00 \pm 7.63$ & $1.00 \pm 0.08$ \\
$\mathbf{1 1 , 4 0 0 \times g ~ s u p e r n a t a n t ~}$ & $130.0 \pm 5.40$ & $0.15 \pm 0.02$ & $19.50 \pm 1.01$ & $79.52 \pm 2.40$ & $1.25 \pm 0.14$ \\
Streptomycin sulfate treated fraction & $79.2 \pm 4.37$ & $0.22 \pm 0.01$ & $17.42 \pm 1.80$ & $71.05 \pm 5.02$ & $1.83 \pm 0.53$ \\
0-60 \% ammonium sulfate fraction & $12.88 \pm 1.42$ & $1.17 \pm 0.08$ & $15.06 \pm 1.56$ & $61.41 \pm 2.58$ & $9.75 \pm 1.20$ \\
DEAE-cellulose fraction & $1.8 \pm 0.20$ & $6.96 \pm 0.68$ & $12.52 \pm 1.12$ & $51.06 \pm 2.69$ & $58.00 \pm 2.16$ \\
Sephadex G-200 fraction & $0.52 \pm 0.06$ & $8.41 \pm 0.30$ & $4.37 \pm 0.67$ & $17.82 \pm 2.30$ & $70.08 \pm 2.81$ \\
\hline
\end{tabular}

Table 3. Effect of composition of incubation medium on Lunularia cruciata L-myo-inositol-1-phosphate synthase activity (values are mean $\pm \mathrm{SE}$ ).

\begin{tabular}{|c|c|c|}
\hline Condition & $\begin{array}{c}\text { Specific activity } \\
{\left[\mu \mathrm{mol}\left(\mathrm{L}-m y 0 \text {-inositol-1-phosphate) } \mathrm{mg}^{-1}(\text { protein }) \mathrm{h}^{1}\right]\right.}\end{array}$ & Percent activity \\
\hline Complete set & $13.1 \pm 0.91$ & $100.00 \pm 7.36$ \\
\hline Without substrate (G-6-P) & 0.0 & 0.0 \\
\hline Without buffer (tris-acetate) & $9.9 \pm 1.25$ & $75.5 \pm 4.08$ \\
\hline Without Co-factor $\left(\mathrm{NAD}^{+}\right)$ & $5.3 \pm 0.14$ & $40.45 \pm 2.44$ \\
\hline Without $\mathrm{NH}_{4} \mathrm{Cl}$ & $8.1 \pm 0.56$ & $61.83 \pm 3.77$ \\
\hline Without 2-mercaptoethanol & $9.6 \pm 0.16$ & $73.28 \pm 3.67$ \\
\hline Heat-killed enzyme & 0.0 & 0.0 \\
\hline
\end{tabular}

Table 4. Effect of monovalent and divalent cations on Lunularia cruciata L-myo-inositol-1-phosphate synthase activity (values are mean $\pm \mathrm{SE}$ ).

\begin{tabular}{|c|c|c|c|}
\hline Cation & Concentration [mM] & $\begin{array}{c}\text { Specific activity } \\
{\left[\mu \text { mol (L-myo-inositol-1-phosphate) } \mathrm{mg}^{-1}(\text { protein }) \mathrm{h}^{1}\right]}\end{array}$ & Percent activity \\
\hline Control & 0 & $8.06 \pm 0.81$ & $100.00 \pm 7.79$ \\
\hline $\mathbf{K}^{+}$ & 5 & $8.60 \pm 0.71$ & $107.56 \pm 8.76$ \\
\hline $\mathrm{Na}^{+}$ & 5 & $6.95 \pm 0.54$ & $86.22 \pm 6.91$ \\
\hline $\mathrm{NH}_{4}^{+}$ & 5 & $11.60 \pm 1.41$ & $143.92 \pm 10.28$ \\
\hline $\mathrm{Mg}^{2+}$ & 5 & $9.43 \pm .0 .69$ & $116.99 \pm 8.87$ \\
\hline $\mathrm{Mn}^{2+}$ & 5 & $7.60 \pm 0.21$ & $94.29 \pm 8.94$ \\
\hline $\mathrm{Ca}^{2+}$ & 5 & $9.01 \pm 1.44$ & $111.78 \pm 4.94$ \\
\hline $\mathrm{Zn}^{2+}$ & 5 & $4.30 \pm 0.65$ & $53.34 \pm 2.32$ \\
\hline $\mathrm{Cu}^{2+}$ & 5 & $5.08 \pm 0.11$ & $62.87 \pm 1.99$ \\
\hline $\mathrm{Hg}^{2+}$ & 5 & $1.65 \pm 0.12$ & $20.47 \pm 1.69$ \\
\hline
\end{tabular}

\section{DISCUSSION}

The present study reports the partial purification and characterization of MIPS for the first time from $L$. cruciata. The enzyme from $L$. cruciata does not show any activity in absence of its specific substrate G-6-P. The enzyme exhibits its optimal activity in presence of co-enzyme NAD ${ }^{+}$and $\mathrm{NAD}^{+}$could not be substituted by $\mathrm{NADP}^{+}$at any concentration. However, it could maintain about $40 \%$ of the total activity when $N A D^{+}$was not added externally. This proves the presence of endogenous $\mathrm{NAD}^{+}$in the molecular architecture of this enzyme which has also been reported earlier (Adhikari and Majumder, 1983; Chhetri et al., 2006b). 
Like all other eukaryotes, the L. cruciata MIPS requires $\mathrm{NH}_{4}{ }^{+}$for its optimal activity in contrast to the divalent cation requiring MIPS of prokaryotes (Majumder et al. 2003). This indicates that the bryophytic MIPS is a type-III aldolase. Among the cations $\mathrm{Na}^{+}$and $\mathrm{Mn}^{2+}$ were mild inhibitors; $\mathrm{Ca}^{2+}$ and $\mathrm{Mg}^{2+}$ were mild stimulators and $\mathrm{Cu}^{2+}, \mathrm{Zn}^{2+}$ and $\mathrm{Hg}^{2+}$ were strong inhibitors of $L$. cruciata MIPS in the order of $\mathrm{Hg}^{2+}>\mathrm{Zn}^{2+}>\mathrm{Cu}^{2+}$ with $\mathrm{Hg}^{2+}$ limiting the enzyme activity to about $20 \%$. The strong enzyme inhibition due to heavy metals suggests that one or more free sulphydryl groups are present within the active site of the enzyme (Nelson and Cox, 2000). The narrow pH optima (7.0-7.5) obtained for L. cruciata MIPS is quite similar to the same obtained for the MIPS from other sources (Donahue and Henry, 1981; Dasgupta et al., 1984; Adhikari and Majumder, 1988; Lohia et al., 1999). The optimum temperature for $L$. cruciata MIPS was found to be 30 ${ }^{\circ} \mathrm{C}$ which is slightly less as compared to that from Spirulina platensis, Euglena gracilis, Oryza sativa (RayChaudhuri et al., 1997), but similar to that from Gleichenia glauca (Chhetri et al., 2005).

The presence of numerous cellular compartments and genetic loci for MIPS indicates the role of this enzyme in the regulation of metabolic flux of inositol (Lackey et al., 2003). Free inositol is channeled for the production of different methylated derivatives, which acts as potent osmolytes for amelioration of oxidative damage during osmotic stress (Bohnert et al., 1995). Increased synthesis of inositol by plants has been observed in salt environment by stress tolerant MIPS protein which is able to function under such stress conditions (Ghosh Dastidar et al., 2006). Induction of the increased production of inositols and its methylated derivatives like ononitol and pinitol have been reported in response to salt stress in several plants (Vernon and Boenert, 1992; Ishitani et al. 1996; Sheveleva et al., 1997). Studies by other workers have revealed its direct role in salinity tolerance (Nelson et al., 1998; Majee et al., 2004), desiccation tolerance (Majee et al., 2005) and extremely high temperature tolerance (Chen et al., 1998, Lamosa et al., 2006). Bryophytes being a highly desiccation and drought tolerant plants may prove to be an ideal candidate for fishing stress tolerant genes. Considering the essential roles of inositols, the present study detailing the investigation on the biosynthesis and regulation of myo-inositol in bryophyte is of fundamental importance.

\section{REFERENCES}

Adhikari J, Majumdar AL (1983) Differences in thermal stability of the fetal and adult brain myo-inositol-1-phosphate synthase. FEBS Lett. 163: 46-49.

Adhikari J, Majumdar AL (1988) L-myo-Inositol-1-phosphate synthase from mammalian brain: partial purification and characterization of the fetal and adult enzyme. Ind. J. Biochem. Biophys. 25: 408-412.

Adhikari J, Majumdar AL, Bhaduri TJ, Dasgupta S, Majumdar AL (1987) Chloroplast as a locale of L-myo-Inositol-1-phosphate synthase. Plant Physiol. 85: 611-614.

Bachhawat N., Mande SC (1999) Identification of the INO 1 gene of Mycobacterium tuberculosis H37 Rv reveals a novel class of Inositol-1phosphate synthase enzyme. J. Mol. Biol. 291: 531-536.

Bachhawat N., Mande SC (2000) Complex evolution of the inositol-1phosphate synthase gene among archea and eubacteria, Trends Genet. 16: 111-113.

Barnett JEG, Brice RE, Corina DL (1970) A colorimetric determination of inositol monophosphates as an assay for D-Glucose-6-phosphate-1L-myoInositol-1- phosphate cyclase. Biochem. J. 119: 183-186.

Biswas BB, Ghosh B, Majumdar AL (1984) Myo-inositol polyphosphates and their role in cellular metabolism: a proposed cycle involving Glucose-6phosphate and myo-Inositol phosphates. In: Rodyn DB (ed), Subcellular biochemistry, Vol. 10, pp 237-280. Plenum Press. London.

Biswas T, Adhikari J, Biswas Choudhuri R, Majumder AL. (1981) Fructose 1, 6-bisphosphatase and myo-Inositol synthase: a phylogenetic search. Ind. J. Biochem. Biophys. 18: 442-444.

Bohnert HR, Nelson DE, Jensen RG (1995) Adaptations to environmental stresses. Plant Cell. 7: 1099-1111.

Bradford MM (1976) A rapid method for the quantitation of microgram quantities of proteins utilizing principle of protein-dye binding. Anal. Biochem. 72: 248-254.

Charalampous F, Chen IW (1966) Inositol-1-phosphate synthase and Inositol 1-phosphatase from Yeast. Methods Enzymol. 9: 698-704.

Chen L, Spiliotis ET, Roberts MF (1998) Biosynthesis of Di-myo-inositol-1, 1'-phosphate, a novel osmolyte in hyperthermophilic archaea. J. Bact. 180: 3785-3792.

Chen L, Zhou C, Yang H, Roberts MF (2000) Inositol-1-phosphate synthase from Archaeoglobus fulgidus is a class II aldolase. Biochemistry. 39:1241512423.

Chen RS, Toribara TY, Warner H (1956) Microdetermination of phosphorous. Anal. Biochem. 28 : 1756-1758.

Chhetri DR, Adhikari J, Mukherjee AK (2006b) NAD+ mediated differential thermotolerance between chloroplastic and cytosolic L-myo-Inositol 1-phosphate synthase from Diplopterygium glaucum (Thunb.) Nakai. Prep. Biochem. Biotech. 36: 307-319.

Chhetri DR, Chiu PF (2004) Identification and characterization of L-myoinositol-1-phosphate synthase from Taxus baccata. J. Phytol. Res. 17: 141146.

Chhetri DR, Choudhuri M, Mukherjee AK, Adhikari J (2005) L-myo-inositol-1phosphate synthase: partial purification and characterization from Gleichenia glauca. Biol. Plant. 49: 59-63.

Chhetri DR, Mukherjee AK, Adhikari J (2006a) Partial purification and characterization of L-myo-inositol-1-phosphate synthase of pteridophytic origin. Acta Physiol. Plant. 28: 101-107.

Dasgupta S, Adhikari J, Majumdar AL (1984) Myo-inositol-1-phosphate synthase from lower plant groups: purification and properties of the enzyme from Euglena gracilis. Physiol. Plant. 61: 412-416.

Donahue T. F., Henry S. A. (1981a). Inositol mutants of Saccharomyces cerevisiae: Mapping the IN01 locus and characterizing alleles of IN01, INO2 and INO4 loci. Genetics 98: 491-503 
Donahue T. F., Henry S. A. (1981b). Myo inositol 1-phosphate synthase: Characteristics of the enzyme and identification of its structural gene in Yeast. J. Biol. Chem. 256: 7077-7085

Escamilla JE, Contreas M, Martinez A, Pina MZ (1982) L-myo-Inositol-1phosphate synthase from Neurospora crassa: Purification to homogeneity and partial characterization. Arch. Biochem. Biophys. 218: 275-285.

Gaitonde MK, Griffiths M (1966) A spectrophotometric method for the determination of microquantities of free inositol in biological material. Anal. Biochem. 15: 532.

Ghoshs Dastidar K, Maitra S, Goswami L, Roy D, Das KP, Majumder AL (2006) An insight into the molecular basis of salt tolerance of L-myo-Inositol 1-P Synthase (PcIN01) from Porteresia coarctata (Roxb.) Tateoka, a halophytic wild rice. Plant Physiol. 140: 1279-1296.

Gumber SC., Loewus MW, Loewus FA (1984) Myo-inositol-1-phosphate synthase from pine pollen: Sulphahydryl involvement at the active site. Arch. Biochim. Biophys. 231: 372-377.

Ishitani M, Majumdar AL, Bornhouser A, Michalowski CB, Jensen RG, Bohnert HJ (1996) Co-ordinate transcriptional induction of myo-inositol metabolism during environmental stress. Plant J. 9: 537-548.

Johnson MD, Sussex IM (1995) 1L-myo-Inositol 1-phosphate synthase from Arabidopsis from thaliana. Plant Physiol. 107: 613-619.

Johnson MD, Wang X (1996) Differentially expressed forms of 1-L-myoInositol 1-phosphate synthase (EC. 5.5.1.4) in Phaseolus vulgaris. J. Biol. Chem. 271: 17215-17218.

Lackey KH, Pope PM, Johnson MD (2003) Expression of 1L-myo-inositol-1phosphate synthase in organelles, Plant Physiol. 132: 2240-2247.

Lamosa P, Gonçalves LG, Rodrigues MV, Martins LO, Raven NDH, Santos H (2006) Occurrence of 1-Glyceryl-1-myo- Inosityl Phosphate in hyperthemophiles. Appl. Environ. Microbiol. 72: 6169-6173.

Loewus FA, Murthy PN (2000) myo-Inositol metabolism in plants. Plant Sci. 150: 1-19.

Loewus MW, Loewus FA (1971) The isolation and characaterisation of D-Glucose 6-phosphate cycloaldolase(NAD dependent) from Acer pseudoplatanus L. cell cultures. Plant Physiol. 48: 255-260.
Lohia A, Hait NC, Majumdar AL (1999) L-Myo Inositol 1-phosphate synthase from Entamoeba histolytica. Mol. Biochem Parasitol.98: 67-79.

Maeda T, Eisenberg F Jr. (1980) Purification, structure and catalytic properties of the 1 L-myo-inositol-1-phospahte synthase from rat testis. J. Biol. Chem. 255: 8458-8464.

Majee M, Mitra S, Ghosh Dastidar K, Pattnaik K, Chatterjee A, Hait NC, Das KP, Majumder AL (2004) A novel salt-tolerant L-myo-inositol -1-phosphate synthase from Porteresia coarctata (Roxb.) Tateoka, a halophytic wild rice: molecular cloning, bacterial overexpression, characterization and functional introgression into tobacco - conferring salt-tolerant phenotype. J. Biol. Chem., 279: 28539-28552.

Majee M, Patra B, Mundree SG, Majumder AL (2005) Molecular cloning, bacterial overexpression and characterization L-myo-inositol-1-phosphate synthase from a monocotyledonous resurrection plant, Xerophyta viscosa Baker J Plant Biochem Biotech. 14:95-99.

Majumder AL, Chatterjee A, Ghosh Dastidar K, Majee M (2003) Diversification and evolution of L-myo-Inositol-1-phosphate synthase. FEBS Lett. 553: 3-10.

Mauck LA, Wong YH, Sherman WR (1980) L-myo-Inositol-1-phosphate synthase from bovine testis: purification to homogeneity and partial characterization. Biochemistry. 19: 3623-3629.

Nelson DE, Rammesmayer G, Bohnert HJ (1998) Regulation of cell-specific inositol metabolism and transport in plant salinity tolerance. Plant Cell. 10: 753-764.

Nelson DL, Cox MM (2000) Lehninger Pinciples of Bochemistry. $3^{\text {rd }}$ edn. Worth Publishers, New York.

RayChoudhury A, Hait NC, Dasgupta S, Bhaduri TJ, Deb R, Majumdar AL (1997) L-myo-Inositol 1-phosphate synthase of plant sources. Plant Physiol. 115: 727-736.

Sheveleva E, Chmara W, Bohnert HJ, Jensen RG (1997) Increased salt and drought tolerance by D-ononitol production in transgenisc Nicotiana tabacum L. Plant Physiol. 115: 1211-1219.

Vernon DM, Bohnert HJ (1992) A novel methyl transferase induced by osmotic stress in the facultative halophyte Mesembryamthemum crystalinum. EMBO J. 11: 2077-2085 